\title{
Skill Level of Rural Leaders towards some Agricultural Technologies in Muda Agriculture Development Authority (Mada-Malaysia)
}

\author{
Wisam Yako Aziz Masso \\ Department of Agriculture Technology, Faculty of Agriculture, Universiti Putra Malaysia (UPM), 43400 Serdang \\ Selangor Malaysia (University of Mosul, Faculty of Agriculture and Forestry, Mosul, Iraq); Wisam.yako@yahoo.com \\ Co-Respond Author: Prof. Norsida Man \\ Norupi45@yahoo.com

\section{Dr. Nolila Binti Mohd Nawi} \\ Department of Agriculture Technology, Faculty of Agriculture, Universiti Putra Malaysia (UPM) \\ 43400 Serdang, Selangor, Malaysia; nolila@putra.upm.edu.my
}

\section{Doi:10.5901/mjss.2016.v7n4p716}

\section{Abstract}

Rice production in MADA is currently reaching an average of four to five tons per hectare. This figure is way better than one or two decades ago.Feder et al. (2010) state that agricultural extension has a bigger potential in improving the productivity of agricultural and also will increase the farmers' incomes through transfer and facilitation of knowledge, skills and technologies. This study is designed to determine the perception level of skill of respondents on paddy farming technologies. The number of the respondents of this study was (260) were selected by random Sampling. SPSS software was used to analyze the data collected, statistics such as frequency, percentage, mean, standard deviation and correlation was used. The perception level of skill among respondents was moderate. The correlation was used to examine the association between Independent Variables and skill towards agriculture technologies on paddy farming.there was a significant relationship between some social, demographic factors and 'level of skill of respondents on paddy farming technologies it is recommended that extension should give to them new training about how to apply new technologies in paddy farming.

Keywords: Rural leaders, skill, agricultural technologies

\section{Introduction}

People all around the world depend immensely on agriculture as one of the main sources to fulfill their basic needs and doubtlessly agriculture is pertinent for the survival of mankind. Agriculture role remains as the food provider for the nation and as an important source of employment, especially for those who live in the rural areas. (Azman, D'Silva et al. 2012).

In Malaysia, agriculture has been identified as an important avenue to strengthen the national Gross Domestic Products (GDP) and thus farhad created job opportunities for $16 \%$ of the population.Generally, the agriculture sector in Malaysia is characterized by the estates' sub-sectors as well as smallholders' sub-sectors. It could further be classified into food and industrial crops. The food subsector includes paddy, vegetables, fruits, meat and fish while the main industrial crops are oil palm, rubber, cocoa and forestry(D'Silva, Samah et al. 2010) .

Malaysia is one of the many countries in our planet, tiny though it is, where food self sufficiency is decreasing, year by year. The weakness of the Malaysian agricultural sector is that it largely produces cash crops and little food. Malaysia is a net food importing country, despite once having produced almost enough food for the local population. It is not that there is no land to produce food: it is just that the priorities are different(Shah, Asmuni et al. 2013).

Now that government has realized that agriculture sector has significant role in supplying foods to people in the country, government starts to reemphasize on the development of agricultural courses in local universities such as biotechnology, holticuture, agribusiness and many others courses in order to produce agriculture specialist in research and development. Agriculture development is now focusing on the high value added product such as fruits, vegetables and livestock. Agriculture sector has achieved positive development during The Eight Malaysia Plan (RMK8). To sustain this positive development the Malaysian government has announced in the 2010 budget that RM6 billion has been 
allocated for agriculture sector. One of the agriculture sectors that can profit from this allocation is the paddy industry (Hayrol, Azizan \& Azahari, 2010).

Paddy farming in Malaysia is one of the first irrigated rice production systems observed in Asia. Indirectly, our first perception, Malaysia is way forward in advancement of paddy farming. These days paddy farming production is quite embarrassing and worrying for national food security level. Many parties are involved to escalate the current position of rice self-sufficiency level. Malaysian government has spent more attention towards rice industry. In developing countries such as Malaysia, rural people have depended on extension worker for technical advice and information(Firdaus, Latiff et al. 2012).

The success of extension programs will be determined to a large degree by the ability of the extension worker to be qualified and competent since the whole extension process is dependent on them to transfer new ideas and technical advice to the rural people. Productivity of the extension organization also highly depends upon the function of extension workers. In fact competent extension workers ensure the success of the extension services and extension organizations as well(Tiraieyari 2009).

Agricultural extension brings about changes through education and communication in farmers attitude, knowledge and skills The role of agricultural extension involves dissemination of information, building capacity of farmers through the use of a variety of communication methods and help farmers make informed decisions (Sinkaiye 2005).

\section{Literature Review}

The term "paddy" means rice cultivated in low land with irrigation. Rice farming in Malaysia can be regarded as one of the origins of the irrigated rice production systems commonly observed in Asia ( Norsida Man2009). In Malaysia, the production of rice has become one of the largest contributors to the economic sector instead of oil palm and rubber. This is mainly due to rice as a staple and vital food that is needed by Malaysians in their daily diet.(Yin, Ismail et al. 2012)

Rice has been a staple food of the Malaysian community and the paddy/rice industry is considered as a strategic industry and always gets special treatment from the government (Nordiana,2008).In the 60's many newly independent nations like Malaysia, considered the improvement of agricultural systems a priority in their planning for the rural development. One of the early developments in the green revolution was the improvement of paddy farming technologies in Peninsular Malaysia. By the 70's Malaysia was comparatively advanced in paddy sector among the Southeast Asian countries through the introduction of modern technologies.(Swanson and Rajalahti 2010)

MADA has been successful in their efforts to improve rice's yield of and solve various problems in the paddy farming for the past two decades through programs that have been carried out. Agricultural innovations that occur as the provision of infrastructure and proper care, the discovery and use of quality seeds, the introduction of agricultural machinery, crop conversion system once a year to twice a year and convert to direct seeding techniques in the Muda area has succeeded in increasing rice production in general.(Man 2009)

Rice production in MADA is currently reaching an average of four to five tons per hectare. This figure is way better than one or two decades ago. However, to meet the needs of our country and overcome the problem of excess imported food and dependency on foreign countries to supply the country's food is primarily the responsibility of the major rice production areas of Malaysia which is MADA and KADA. Through this awareness, rice production and the degree they put the target of 10 tonnes per hectare to be achieved can be increased.(Roslan, Abdullah et al. 2012)

Therefore, delivery and effective implementation of extension activities is depends on the knowledge, skills and expertise of extension agents. Quality of extension agents should be increased from time to time in line with changes in agriculture's world and the importance to meet the needs of farmers to achieve the goal of educating and empowering them so that agriculture can be independent.(Chan, Lee et al. 2006)

Feder et al. (2010) state that agricultural extension has a bigger potential in improve the productivity of agricultural and also will increase the farmers' incomes through transfer and facilitation of knowledge, skills and technologies. The Impact of agricultural extension are positively proven in some country according to Davies et al. (2012) that the rates of return on economic and social contribution of agricultural extension program in some countries are higher. Birner et al. (2009) add that there is a gap on the performance and impact of extension if refer to the knowledge by the farmers. Agricultural extension is one of the important part that can make the transfer of technology successful. The new ideas and knowledge are important for the farmers to increase their yield to the optimum level. According to Gonzales et al. (1982) one of the mission in extension is to educate the people.

There are two types of leader: 1) opinion leaders; and 2) the leaders of the implementation. It can be opinion leaders through the dissemination of ideas and the technical recommendations between the audience. It can also be through implementation leaders in a democratic way involve farmers in policy development, planning, implementation and 
evaluation of extension programs.(Rogers 2010)

Rogers (2010) also said that rural leaders are the people who are able in an informal manner that the influence relatively frequently on the behavior and attitudes of others towards what is desirable. As the rural leaders play a role in important programs in agricultural extension, so the agricultural extension is a connection process at two-stages: 1) Area Agricultural Extension agencies with rural leaders; 2) rural leader with other farmers.

In the Malaysian context, it is often mentioned that there is a disparity in use agricultural technologeis (such as traditional versus modern technologies) and level of skill regarding to paddy farming between the various groups of the farming community in Malaysia. However, not many studies were carried out to determine the level of skill of respondents on paddy farming technologies in Malaysia. Thus, this study is designed to determine the perception level of skill of respondents on paddy farming technologies.

\section{The Objectives of the Study}

The specific objectives of the study were:

1. Identifying characteristics of respondents.

2. Determine the perception levels of skill of paddy farming technologies of the respondents.

3. Determine the relationship between socio demographic factors and perception level of skill of paddy farming technologies for the respondents.

\section{Methodology}

The number of the respondents of this study was (260) were selected from 27 Regional in muda agriculture development authority (MADA). We choose 10 rural leaders from each regional by random sampling. We delete 10 responded questionnaires, due to the incomplete data. The data collected face-to-face interview based on a structured questionnaire from muda agriculture development authority (MADA). The data collection process started in April and was completed in June 2015.five Likert was used to identify the level of skill of respondents. The Cronbach alpha value obtained for all the skill level was $(0.793)$ exceeding. SPSS software was used to analyze the data collected, statistics such as frequency, percentage, mean, standard deviation and correlation was used.

\section{Results and Discussion}

Farmers' demographic attributes: The demographic attributes of respondents (table 1 ) show that most of them (25.8 \%) were in the range of $43-48$ year. Most of the respondents were educated secondary level (30.4\%) and about (15.8\%) they have a degree.Most of the respondents(67.7) are full time farmer. More than half of the respondents (52.7\%) they have above 20 years experience in paddy farming.Most of the respondents (53.5\%) they have (6-9) person in the family. As the length of functional service as a rural leader the (26.6) percent of the respondents have (10-14 years) in functional service, but 32.4 percent have (15-19 years) in functional service as a rural leader. For the yield of paddy table shows $21.2 \%$ of the respondents have below ( 2 tons) of the yield of paddy, then $25.4 \%$ of the respondents have (3-5 tons) of the yield of paddy

Table (1): Profile of the Respondents

\begin{tabular}{|l|c|c|}
\hline CHARACTERISTICS & $\mathbf{n} \mathbf{( 2 6 0 )}$ & Percentage \\
\hline AGE & Frequency & Percent \\
\hline 31-36 YEARS & 66 & 25.4 \\
\hline $37-42$ YEARS & 53 & 20.4 \\
\hline 43-48 YEARS & 67 & 25.8 \\
\hline 49-54 YEARS & 51 & 19.6 \\
\hline ABOVE 55 YEARS & 23 & 8.8 \\
\hline LEVEL OF EDUCATION & Frequency & Percent \\
\hline NO EDUCATION & 29 & 11.2 \\
\hline PRIMARY LEVEL & 62 & 23.8 \\
\hline SECONDARY LEVEL & 79 & 30.4 \\
\hline FOUNDATION & 35 & 13.5 \\
\hline
\end{tabular}




\begin{tabular}{|l|c|c|}
\hline DIPLOMA & 14 & 5.4 \\
\hline DEGREE & 41 & 15.8 \\
\hline OCCUPATION & Frequency & Percent \\
\hline FULL TIME FARMERS & 176 & 67.7 \\
\hline PART TIME FARMERS & 84 & 32.3 \\
\hline EXPERIENCE & Frequency & Percent \\
\hline 8-13 YEARS & 71 & 27.3 \\
\hline 14-19 YEARS & 52 & 20.0 \\
\hline ABOVE 20 YEARS & 137 & 52.7 \\
\hline FAMILY SIZE & Frequency & Percent \\
\hline 2-5 PERSON & 55 & 21.2 \\
\hline 6-9 PERSON & 139 & 53.5 \\
\hline ABOVE 10 PEOPLE & 66 & 25.4 \\
\hline LENGTH OF FUNCTIONAL SERVICE AS ARURAL LEADER & Frequency & Percent \\
\hline 5-9 YEARS & 61 & 23.3 \\
\hline 10-14 YEARS & 70 & 26.6 \\
\hline $15-19$ YEARS & 85 & 32.4 \\
\hline ABOVE 20 YEARS & 44 & 16.7 \\
\hline YIELD OF PADDY & Frequency & Percent \\
\hline BELOW 2 TONS & 55 & 21.2 \\
\hline 3-5 TONS & 66 & 25.4 \\
\hline 6-8 TONS & 54 & 20.8 \\
\hline 9-11 TONS & 44 & 16.9 \\
\hline ABOVE 12 TONS & 41 & 15.8 \\
\hline
\end{tabular}

Table (2) indicates the rank of level of levels of skill of paddy farming technologies of the respondents. Skill from highest to lowest based on the moon. The rank is as follows, the skill dimension with the highest mean is "you can handle the tractor" (4.13), this mean rural leaders can handle the tractor when they face any problems about it . On the other side, the lowest mean is "you give additional information about the new message that is given to farmers" (3.61).this is mean rural leaders they don't give any additional information when they receive new text from agricultural agency or from agricultural extension to farmers.

Table (2): Perceptions toward the Skill of the respondents

\begin{tabular}{|l|c|c|c|c|c|c|c|}
\hline STATEMENTS OF SKILL & \multicolumn{4}{|c|}{ Frequencyl(\%) } \\
\cline { 2 - 6 } & $\mathbf{1}$ & $\mathbf{2}$ & $\mathbf{3}$ & $\mathbf{4}$ & $\mathbf{5}$ & Mean & SD \\
\hline YOU CAN HANDLE THE TRACTOR & 1.9 & 5.3 & 16.0 & 45.6 & 30.0 & 4.13 & .915 \\
\hline YOU HANDLE THE FERTILIZING EQUIPMENT'S & 4.6 & 3.8 & 14.4 & 50.6 & 25.5 & 3.98 & .926 \\
\hline $\begin{array}{l}\text { YOU HAVE A SKILL TO DIFFERENTIATE THE GOOD RICE VARIETIES RESISTANT TO } \\
\text { DISEASES }\end{array}$ & 1.5 & 6.5 & 7.2 & 46.4 & 37.3 & 3.93 & .874 \\
\hline $\begin{array}{l}\text { YOU HAVE A SKILL USING THE COMPUTER IN RECORDING THE FARM RECORDS OR } \\
\text { LOOKING FOR THE INFORMATION }\end{array}$ & 3.0 & 9.1 & 10.3 & 51.3 & 25.1 & 3.90 & .983 \\
\hline YOU CAN USE THE RICE TRANSPLANTED & 1.5 & 6.8 & 11.4 & 55.9 & 23.2 & 3.87 & .996 \\
\hline YOU HAVE THE ABILITY TO TEACH FARMER HOW TO USE THE NEW MACHINE & 3.8 & 7.6 & 18.3 & 46.8 & 22.4 & 3.83 & .853 \\
\hline $\begin{array}{l}\text { YOU HAVE A SKILL TO DIFFERENTIATE THE PESTICIDE USAGE FOR THE RIGHT PEST AND } \\
\text { DISEASES }\end{array}$ & 1.5 & 10.3 & 27.8 & 37.3 & 22.1 & 3.77 & 1.009 \\
\hline YOU HAVE A SKILL TO DIFFERENTIATE QUALIFIED SEED & 3.4 & 8.0 & 34.2 & 27.4 & 25.9 & 3.69 & .982 \\
\hline YOU CAN TEACH FARMERS HOW TO USE A SUITABLE AMOUNT OF HERBICIDE & 1.1 & 6.1 & 20.5 & 51.7 & 19.4 & 3.65 & 1.060 \\
\hline $\begin{array}{l}\text { YOU GIVE ADDITIONAL INFORMATION ABOUT THE NEW MESSAGE THAT IS GIVEN TO } \\
\text { FARMERS }\end{array}$ & 1.9 & 7.6 & 30.8 & 45.2 & 13.3 & 3.61 & .883 \\
\hline Total average meanS & & & $\mathbf{3 . 8 3}$ & $\mathbf{0 . 9 4}$ \\
\hline
\end{tabular}

Table (3) shows the percentage, mean and standard deviation for the perception level of skill among respondents. The table shows the respondents have a moderate level of perception skill on paddy farming technologies (52.3\%) at 3.83 mean, and for low level is $38.8 \%$ and for the percentage of high level is (8.9\%). 
Table(3): Level of skill of the respondents on paddy farming technologies $n=260$

\begin{tabular}{|l|c|c|c|c|}
\hline LEVEL & Frequency & Percentage & Mean & SD \\
\hline HIGH (3.67-5.0) & 101 & 8.9 & \multirow{2}{*}{3.83} & 0.94 \\
\cline { 1 - 3 } MODERATE (2.34-3.66) & 136 & 52.3 & & \\
\cline { 1 - 3 } LOW (1-2.33) & 23 & 38.8 & & \\
\hline TOTAL & 260 & 100.0 & & \\
\hline
\end{tabular}

Correlation Analysis between Independent Variables and skill statements: Pearson correlation was used to examine the association between Independent Variables and skill towards agriculture technologies of paddy farimg. Based on the results presented in Table 4, level of education correlate negitivly with skill of the respondents $(r=0.002, P<0.01)$ this is because most of respondents have secondary level of education this is mean they have low level of education they canot understand how to apply new technologies in their farm because their education level are low. Follow by, yield of paddy has positive correlate with skill of the respondents $(r=0.0260, P<0.05)$ we can see from this results rural leaders they want to learn every thing about new technologies on paddy farming to have very good harvest.Other personal characteristics (Age,occupation in paddy farming, years of experience in paddy farming, family size , length of functional service as a (rural leader) have no significant relationship with skill of respondents towards paddy farming technologies.

Table (4): Correlation Coefficient between Independent Variables and Attribute statements $(n=260)$

\begin{tabular}{|c|l|c|c|l|}
\hline No & INDEPENDENT VARIABLES & $\mathbf{r}$ & $\mathbf{P}$ (2-tailed) & Remark \\
\hline 1. & AGE & 0.013 & 0.420 & Fail to Reject Ho \\
\hline 2. & LEVEL OF EDUCATION & $-0.18-^{\star \star}$ & 0.002 & Reject $\mathrm{H}_{0}$ \\
\hline 3. & OCCUPATION IN PADDY FARMING & $-0.007-$ & 0.455 & Fail to Reject $\mathrm{H}_{0}$ \\
\hline 4. & YEARS OF EXPERIENCE IN PADDY FARMING & 0.047 & 0.227 & Fail to Reject $\mathrm{H}_{0}$ \\
\hline 5. & FAMILY SIZE & $-0.063-$ & 0.155 & Fail to Reject $\mathrm{H}_{0}$ \\
\hline 6. & LENGTH OF FUNCTIONAL SERVICE ASA (RURAL LEADER) & $-0.018-$ & 0.383 & Fail to Reject $\mathrm{H}_{0}$ \\
\hline 7. & YIELD OF PADDY & $0.040^{\star}$ & 0.0260 & Reject $\mathrm{H}_{0}$ \\
\hline
\end{tabular}

**. Correlation is significant at the 0.01 level (1-tailed).

*. Correlation is significant at the 0.05 level (1-tailed)

\section{Conclusion}

Conclusion Based on the mentioned results, it can be concluded that the respondents had a negative perception toward some paddy farming technologies, such as: 1) You can teach farmers how to use a suitable amount of herbicide 2) You Give additional information about the new message that is given to farmers. It is mean that rural leaders don't have good skill to apply new technologies in paddy farming. Extension agents need to teach them the correct methods of using these technologies. To improve such perceptions it is recommended that extension should give to them new training about how to apply new technologies in paddy farming ,and dependence on the results of previous research, especially the research used agricultural technologies and should application it by department of agriculture in order to benefit from this results. Rural leaders had a weak perception towards intangible impacts of modern techno technologies on soil, water and the environment. They must think about such important issues.

\section{References}

Azman, A., J. L. D'Silva, B. A. Samah, N. Man and H. A. M. Shaffril (2012). "Comparative study on sustainable agriculture knowledge among Malaysian contract farmers." American Journal of Applied Sciences 9(5): 673.

Chan, C., T. Lee and M. CH (2006). "Predicting paddy soil productivity."

D'Silva, J. L., B. A. Samah, H. A. M. Shaffril and M. A. Hassan (2010). "Factors that influence attitude towards ICT usage among rural community leaders in Malaysia." Australian Journal of Basic and Applied Sciences 4(10): 5214-5220.

Firdaus, R. R., I. A. Latiff and P. Borkotoky (2012). "The impact of climate change towards Malaysian paddy farmers." Journal of Development and Agricultural Economics 5(2): 57-66.

Man, N. (2009). "Factors affecting the decision making in off farm employment among paddy farmers in Kemasin Semerak." Pertanika Journal of Social Sciences \& Humanities 17(1): 7-15.

Rogers, E. M. (2010). Diffusion of innovations, Simon and Schuster.

Roslan, N. A., A. M. Abdullah, M. M. Ismail and A. Radam (2012). "Determining Risk Attitudes of Paddy Farmers in KETARA Granary, 
Malaysia." International Journal of Social Science and Humanity 2(3): 225.

Shah, J. A., A. Asmuni and A. Ismail (2013). "Roles of Extension Agents Towards Agricultural Practice in Malaysia." International Journal on Advanced Science, Engineering and Information Technology 3(1): 59-63.

Sinkaiye, T. (2005). "Agricultural extension participatory methodologies and approaches." Agricultural Extension in Nigeria: 220-233.

Swanson, B. E. and R. Rajalahti (2010). Strengthening Agricultural Extension and Advisorty Systems: Procedures for Assessing, Transforming, and Evaluating Extension Systems, Agriculture and Rural Development, World Bank.

Tiraieyari, N. (2009). "The importance of cultural competency for agricultural extension worker in Malaysia." The Journal of International Social Research 2(8): 411-421.

Yin, S. A., A. Ismail and S. Z. Zulkifli (2012). "Copper and zinc speciation in soils from paddy cultivation areas in Kelantan, Malaysia." Acta Biologica Malaysiana 1(1): 26-35.

Hayrol Azril, M.S., Azizan, A., Azahari., I., (2010). The ninth Malaysian plan and agriculture extension officer competency: A combination for intensification of paddy industry in Malaysia. The Journal of International Social Research, Volume 3 / 10 Winter 2010.

Nordiana, I. 2008. Factors Affecting Paddy Production Under Integrated Agriculture Development Area of North Terengganu (IADA KETARA). International Plantation Exhibition and Conference (IpiCEX) 2008.

Gonzalez, I. M. (1982). The professional competencies needed by extension agents in the Pennsylvania Cooperative Extension Service. Unpublished doctoral dissertation, Pennsylvania State University, University Park.

Feder, G., Anderson, J.R., Birner, R., \& Deininger, K.W. (2010). Promises and realities of community-based agricultural extension. IFPRI discussion paper 959, International Food Policy Research Institute (IFPRI).

Davis, K, Nkonya, E, Kato, E, Mekonnen, D, Odendo, M, Miiro, R, et al.(2012).Impact of farmer field schools on agricultural productivity and poverty in East Africa.World Development, 40 (2), pp. 402-413

Birner, R., K. Davis, J. Pender, E. Nkonya, P. Anandajayasekeram, J. Ekboir, A. Mbabu et al. (2009). "From Best Practice to Best Fit: A Framework for Designing and Analyzing Pluralistic Agricultural Advisory Services Worldwide." Journal of Agricultural Education and Extension 15 (4): 341-355. 